\title{
How is the source of food poisoning outbreaks established? The example of three consecutive Salmonella enteritidis PT4 outbreaks linked to eggs
}

\author{
R L Salmon, S R Palmer, CD Ribeiro, P Hutchings, T J Coleman, F J A Willis, T N Allsup, \\ W N Ritchie
}

\begin{abstract}
Three consecutive outbreaks of Salmonella enteritidis PT4 occurred in Wales in 1989 in which epidemiological and microbiological investigation established eggs as the likely source although kitchen inspection and food preparation histories suggested other vehicles of infection. This paper examines the contribution of analytical epidemiology in attributing causation, with particular reference to those limitations which are regarded as inherent in epidemiological evidence. Such evidence, implicating eggs in the three outbreaks, fulfilled $6 / 7$ widely accepted criteria for causation; data to assess the seventh were lacking. Collaboration between different agencies and professionals in investigating outbreaks is very important.
\end{abstract}

PHLS Communicable Disease Surveillance Centre (Welsh Unit), Abton House, Wedal Road, Cardiff CF4 3QX United Kingdom R I Salmon $S$ R Palmer

Cardiff Public Health

Laboratory

University Hospital of

Wales, Cardiff

C D Ribeiro

Environmental Health

Department, Cardiff

City Council, Wood

St, Cardiff

$P$ Hutchings

Hereford Public

Health Laboratory,

County Hospital,

Hereford, United

Kingdom

T J Coleman

Environmental Health

Department,

Brecknock Borough

Council, Hay-on-Wye,

Powys, United

Kingdom

F J A Willis

Veterinary

Investigation Centre,

Government

Buildings,

Whittington Road,

Worcester, United

Kingdom

T N Allsup

Powys Health

Authority, Mansion

House, Bronllys,

Powys, United

Kingdom

W N Ritchie

Correspondence to:

Dr Salmon

Accepted for publication May 1991
The safety of food is a topic to which, latterly, public and professionals have devoted high levels of interest and attention. ${ }^{12}$ A Food Safety Bill is before parliament and the government's committee on the microbiological safety of food (the Richmond Committee) has recently published an authoritative report. ${ }^{3}$ There is agreement that the level of food borne illness revealed by surveillance data has increased. ${ }^{2-4}$ The causes have been the subject of debate, enteritidis PT4 epidemic. ${ }^{5}$ In considering outbreak management ${ }^{3}$ the Richmond Committee took what its chairman described as a philosophical approach, ${ }^{6}$ and considered the problem of tracing the origin of a food which has been implicated as the cause. It did not, however, address the specific problem of the nature of the evidence required to implicate a particular food in the first place, although it does point out the severe economic and social consequences if this is done incorrectly. A consideration of how professionals and agencies cooperate and investigate problems is relevant to this.

\section{Outbreak 1}

Five out of 11 people who attended a private New Year's Eve party reported gastroenteritis which occurred within 26 hours. Vol-au-vents made from leftover Christmas turkey were initially suspected, because of the less than ideal, but not uncommon, handling practices to which the turkey was subject.

During the second week after the function, all attenders completed a postal questionnaire particularly on the relative contribution made by egg consumption to the continuing Salmonella enquiring about symptoms and asking them to indicate the foods they did and did not eat from a list of the 13 items available. Ten of 11 submitted faecal specimens. Seven, including the five with symptoms, were positive for $S$ enteritidis PT4. All five with symptoms ate cheesecake, compared with only one out of six guests who did not have symptoms ( $p=0.013$ Fisher's exact test-one tailed). The individual who ate cheesecake but remained well was negative for $S$ enteritidis PT4. The two further individuals positive for $S$ enteritidis PT4 said they did not eat cheesecake. The cheesecake consisted of a crushed biscuit and margarine base which had been warmed, filled with cream cheese, cream, lemons, gelatine and the yolks of raw eggs, but not cooked further. It was prepared at home at midday on New Year's Eve, refrigerated, and eaten at about $8.00 \mathrm{pm}$. None of 12 other foods which were served at the party was associated with illness.

No cheesecake and no eggs remained for examination. The source of the eggs could not be traced.

\section{Outbreak 2}

Three cases of $S$ enteritidis PT4 gastroenteritis occurred on the same day among staff at a modern office block where about 1400 people worked. The first two attributed their illness to a meal taken at a Mexican restaurant four days earlier but the only factor they had in common with the third case was their employment in the office block. Additional cases (defined as three or more motions in 24 hours and/or a faecal specimen positive for $S$ enteritidis PT4) were ascertained from company sickness records (22 cases) and by faecal sampling of 41 asymptomatic catering staff (six cases).

Kitchen inspection revealed the following. Poultry was defrosted under running water in a sink adjacent to the main salad and sandwich preparation area; the cold room was cramped and in frequent use, making attainment of a satisfactory storage temperature difficult; and cleaning cloths for raw and prepared food surfaces were not differentiated. Cross contamination from poultry to prepared foods was initially thought to be the cause of the outbreak.

\section{INVESTIGATION OF THE OUTBREAK}

\section{Laboratory investigation}

Faecal specimens were submitted from all 22 cases ascertained from sickness records and from 41 asymptomatic catering staff. Faeces were cultured for Campylobacter, Salmonella and Shigella species by conventional methods. 
Table I Food specific party (outbreak 1) attack rates-New Year's

\begin{tabular}{|c|c|c|c|c|c|c|}
\hline \multirow[b]{2}{*}{ Food } & \multicolumn{2}{|c|}{ Eaten } & \multicolumn{2}{|c|}{ Not eaten } & \multirow[b]{2}{*}{$R R$} & \multirow[b]{2}{*}{$p$} \\
\hline & $I l^{a}$ & Well & $I l^{a}$ & Well & & \\
\hline $\begin{array}{l}\text { Quiche } \\
\text { Cheesecake } \\
\text { Chocolate biscuit/cake } \\
\text { Swiss roll } \\
\text { Christmas cake } \\
\text { Mince pies } \\
\text { Sausage rolls } \\
\text { Cheese straws } \\
\text { Vol-aux-vents } \\
\text { Blue cheese dip } \\
\text { Cheese and pineapple } \\
\text { sticks }\end{array}$ & $\begin{array}{l}2 \\
5 \\
1 \\
2 \\
0 \\
0 \\
3 \\
3 \\
4 \\
3\end{array}$ & $\begin{array}{l}4 \\
1 \\
2 \\
2 \\
1 \\
2 \\
4 \\
2 \\
2 \\
6 \\
3\end{array}$ & $\begin{array}{l}3 \\
0 \\
4 \\
2 \\
5 \\
4 \\
1 \\
2 \\
1 \\
2\end{array}$ & $\begin{array}{l}1 \\
5 \\
4 \\
4 \\
5 \\
4 \\
2 \\
3 \\
0 \\
3\end{array}$ & $\begin{array}{l}0.44 \\
6.00 \\
0.67 \\
1.50 \\
0 \\
0 \\
1.50 \\
1.50 \\
0.4 \\
1.25\end{array}$ & $\begin{array}{l}\text { NS } \\
<0.025 \dagger \\
\text { NS } \\
\text { NS } \\
\text { NS } \\
\text { NS } \\
\text { NS } \\
\text { NS } \\
\text { NS } \\
\text { NS }\end{array}$ \\
\hline $\begin{array}{l}\text { Cheese and pineapple } \\
\text { sticks }\end{array}$ & 3 & 4 & 0 & 2 & 0 & NS \\
\hline \multicolumn{7}{|c|}{$\begin{array}{l}{ }^{a} \text { Clinical gastroenteritis (abdominal pain and diarrhoea: mode } \\
40 \text { episodes } / 24 \text { h; range } 10-70 \text { episodes) } \\
\text { t Fisher's Exact test (one tailed) } \\
\text { RR = relative risk }\end{array}$} \\
\hline \multicolumn{7}{|c|}{ Epidemiological Investigation } \\
\hline
\end{tabular}

A case-control study was undertaken using controls identified by taking from company records the name of every sixth employee working over the two days prior to the date of onset of illness in the index cases. Controls were not asked to submit faecal samples.

Cases and controls received a structured questionnaire enquiring about symptoms, attendance and meals at the office block, the use of water fountains and vending machines, the individual food items consumed at the office block, and meals eaten out elsewhere.

Risk factors were analysed using the MantelHaenszel version of the $\chi^{2}$ test, except when an expected value in a $2 \times 2$ table was $<5$, when Fisher's Exact test was used.

A subset of early cases with dates of onset during the first five days of the outbreak was subsequently defined. Risk factors were reexamined by comparing this group with the original controls in order to minimise the possible confounding effect of including secondary cases and asymptomatic carriers (who might have acquired the infection from other sources).

\section{Findings}

All 31 cases and 66 of 80 controls ( $83 \%$ ) replied. Two controls had not attended the office and six had symptoms which fulfilled the case definition. Analysis was therefore based on 37 cases and 58 controls. Thirty one cases had symptoms and six, all catering staff, were asymptomatic excretors. Of the 31 cases 30 had diarrhoea (three or more motions per day), 28 had abdominal pain, 24 had headache (usually described as occipital), seven had vomiting, and four had blood in their stools. The mean duration of symptoms was $4.5 \mathrm{~d}$ (SD $3.9 \mathrm{~d}$; range 0-16 d). The epidemic curve (figure) in the 30 symptomatic cases whose date of onset was known was consistent with an initial common source of infection.

Onset of symptoms in cases of $\mathrm{S}$ Enteritidis outbreak 2

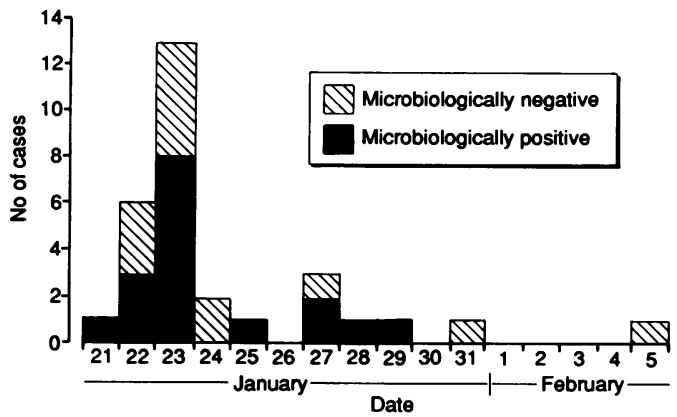

Twenty four symptomatic cases submitted faecal specimens and 17 were positive for $S$ enteritidis PT4. One symptomatic positive case had abdominal pain only; the remaining 16 had diarrhoea among other symptoms.

Cases were significantly associated with eating lunch in the canteen on certain days and with eating food from a mid-morning snack trolley, (table II). Twenty five out of 34 cases ate handled foods (salads or sandwiches) compared with 19 out of 57 controls (odds ratio 6.0, p $<0.00025$ ). Although sandwiches overall were not significantly associated with illness, of eight different types available, one type alone, egg sandwiches, was significantly associated (6/36 cases $v 0 / 57$ controls; p < 0.005). (Egg was not used as a binding agent for sandwiches with other fillings.) Fifteen of 37 cases ate food containing eggs (either hot or cold) compared with seven of 58 controls (odds ratio 5.0; $<<0.0025$ ). Eighteen of 37 cases ate handled food not containing egg compared with 11 of 58 controls (odds ratio 2.5; $\mathrm{p}<0.05$ ). However multivariate analysis showed consumption of food containing eggs to be significantly associated with illness, independently of canteen lunches, the midmorning snack trolley, and handled foods not containing egg ( $p<0.05$ for each).

Analysis of early cases confirmed and strengthened the association with eggs. Twelve of 23 early cases ate egg containing foods compared with seven of 58 controls (odds ratio 8.0; $\mathrm{p}<0.00025)$

Salmonellae were not isolated from a raw chicken from the batch used over the outbreak period. The eggs were traced by the Environmental Health Department to a producer/ wholesaler whose flocks were claimed free of $S$ enteritidis but who had bought in extra eggs from other farms over the critical period.

\section{Outbreak $3^{7}$}

Twelve of 14 people attending a private dinner party developed diarrhoea and vomiting 12-36 hours afterwards. Suspicion fell initially on the main course, sea trout.

\section{INVESTIGATION OF THE OUTBREAK}

Food histories were taken from all guests by the environmental health officer. Twelve of 12 symptomatic guests ate sea trout compared with neither of two who were both well who did not $(p=0.011$, Fisher's Exact test, two tailed). None of 12 other food items was associated with illness (table III). Faecal samples were submitted from 13 guests. Faeces were cultured for Campylobacter, Salmonella and Shigella species by conventional methods. $S$ enteritidis PT4 was isolated from all samples. One guest who had remained well did not submit a sample.

The trout was one of three purchased three days previously from a market stall and stored in the hostess's domestic deep freeze. It was defrosted on the morning of the party. In the early afternoon a stuffing of spinach, sorrel, tarragon, parsley, raw egg, which had been broken at the time of preparation, and breadcrumbs mixed in white wine and vermouth, was made up. The trout was stuffed before being baked, immediately, in foil 
Table II Food preference table-office outbreak (outbreak 2)

\begin{tabular}{|c|c|c|c|c|c|c|}
\hline \multirow[b]{2}{*}{ Food } & \multicolumn{3}{|c|}{ Cases $(n=37)$} & \multicolumn{3}{|c|}{ Early cases ( $n=23$ ) } \\
\hline & $\begin{array}{l}\text { No } \\
\text { exposed }\end{array}$ & $\begin{array}{l}\text { Odds } \\
\text { ratiot }\end{array}$ & $p$ & $\begin{array}{l}\text { No } \\
\text { exposed }\end{array}$ & $\begin{array}{l}\text { Odds } \\
\text { ratiot }\end{array}$ & $p$ \\
\hline \multicolumn{7}{|l|}{ Canteen lunch } \\
\hline 19.1 .89 & 18 & $2 \cdot 7$ & $<0.025$ & 10 & $2 \cdot 2$ & NS \\
\hline 20.1.89 & 22 & $3 \cdot 8$ & $<0.005$ & 13 & $3 \cdot 3$ & $<0.025$ \\
\hline 21.1 .89 & 9 & 3.3 & $<0.05$ & 7 & $4 \cdot 6$ & $<0.025^{\star}$ \\
\hline 22.1 .89 & 6 & $1 \cdot 0$ & NS & 3 & 0.8 & NS \\
\hline 23.1.89 & 18 & $2 \cdot 9$ & $<0.025$ & 10 & $2 \cdot 4$ & NS \\
\hline Snack trolley items & 5 & Undefined & $<0.01^{\star}$ & 4 & Undefined & $<0.01^{\star}$ \\
\hline Salads & 12 & $5 \cdot 2$ & $<0.005$ & 10 & $8 \cdot 0$ & $<0.001^{\star}$ \\
\hline Sandwiches & 16 & $2 \cdot 4$ & NS & 11 & $2 \cdot 6$ & NS \\
\hline Corned beef & 3 & $1 \cdot 2$ & NS & 2 & $1 \cdot 3$ & NS \\
\hline Beef & 1 & $1 \cdot 6$ & NS & 1 & $2 \cdot 6$ & NS \\
\hline Luncheon meat & 1 & $1 \cdot 6$ & NS & 1 & $2 \cdot 6$ & NS \\
\hline Tuna & 5 & $1 \cdot 7$ & NS & 3 & $1 \cdot 6$ & NS \\
\hline Tongue & 1 & Undefined & NS & 1 & Undefined & \\
\hline Egg & 6 & Undefined & $<0.005^{\star}$ & 4 & Undefined & $<0.025^{\star}$ \\
\hline Salad & 2 & $0 \cdot 8$ & NS & 2 & $1 \cdot 3$ & NS \\
\hline Cheese & 11 & $2 \cdot 3$ & NS & 6 & 1.9 & NS \\
\hline \multirow{2}{*}{\multicolumn{7}{|c|}{$\begin{array}{l}\text { Handled foods } \\
\text { (salads/sandwiches) }\end{array}$}} \\
\hline & 25 & $6 \cdot 0$ & $<0.0025$ & 19 & $10 \cdot 3$ & $<0.00005$ \\
\hline \multirow{3}{*}{$\begin{array}{l}\text { Handled foods not } \\
\text { containing egg } \\
\text { Chicken }\end{array}$} & 15 & $5 \cdot 0$ & $<0.0025$ & 12 & $9 \cdot 0$ & $<0.00025$ \\
\hline & 18 & $2 \cdot 5$ & $<0.05$ & 11 & $2 \cdot 9$ & $<0.05$ \\
\hline & 4 & $1 \cdot 6$ & NS & 3 & $2 \cdot 0$ & NS \\
\hline
\end{tabular}

† Controls $\mathrm{n}=\mathbf{5 8}$

$\star$ Fisher's Exact test (one tailed)

Table III Food specific attack rates-private dinner party (outbreak 3)

\begin{tabular}{|c|c|c|c|c|c|c|}
\hline \multirow[b]{2}{*}{ Food } & \multicolumn{2}{|c|}{ Eaten } & \multicolumn{2}{|c|}{ Not eaten } & \multirow[b]{2}{*}{$R R$} & \multirow[b]{2}{*}{$p$} \\
\hline & $I l l^{a}$ & Well & $I l l^{a}$ & Well & & \\
\hline $\begin{array}{l}\text { Chicken terrine } \\
\text { Sea trout } \\
\text { Orange and watercress }\end{array}$ & $\begin{array}{r}8 \\
12\end{array}$ & $\begin{array}{l}1 \\
0\end{array}$ & $\begin{array}{l}4 \\
0\end{array}$ & $\begin{array}{l}1 \\
2\end{array}$ & $\begin{array}{l}1 \cdot 11 \\
\text { Undef }\end{array}$ & $\begin{array}{l}\text { NS } \\
0.011 \dagger\end{array}$ \\
\hline $\begin{array}{l}\text { salad } \\
\text { Tomatoes } \\
\text { Red pepper/fennel } \\
\text { Lettuce } \\
\text { Cucumber yoghurt } \\
\text { New potatoes } \\
\text { Strawberries } \\
\text { Cream } \\
\text { Fromage frais } \\
\text { Cheeses }\end{array}$ & $\begin{array}{r}8 \\
5 \\
4 \\
6 \\
7 \\
11 \\
12 \\
5 \\
5 \\
9\end{array}$ & $\begin{array}{l}2 \\
1 \\
1 \\
1 \\
0 \\
1 \\
2 \\
0 \\
1 \\
2\end{array}$ & $\begin{array}{l}4 \\
7 \\
8 \\
6 \\
5 \\
5 \\
1 \\
0 \\
7 \\
7 \\
7\end{array}$ & $\begin{array}{l}0 \\
1 \\
1 \\
1 \\
2 \\
1 \\
0 \\
2 \\
1 \\
0\end{array}$ & $\begin{array}{l}0.80 \\
0.95 \\
0.90 \\
1.0 \\
1.4 \\
1.83 \\
\text { Undef } \\
1 \cdot 29 \\
0.95 \\
0.82\end{array}$ & $\begin{array}{l}\text { NS } \\
\text { NS } \\
\text { NS } \\
\text { NS } \\
\text { NS } \\
\text { NS } \\
\text { NS } \\
\text { NS } \\
\text { NS } \\
\text { NS }\end{array}$ \\
\hline
\end{tabular}

a Clinical gastroenteritis

$\dagger$ Fisher's Exact test (one tailed)

$\mathbf{R R}=$ relative risk; Undef $=$ undefined

for $25 \mathrm{~min}$ at a setting of $160^{\circ} \mathrm{C}$ in a "circlotherm" oven. Subsequently the fish was placed in the refrigerator before it had reached room temperature, in order to accelerate cooling, and left for $7 \mathrm{~h}$. It was removed about $1 \mathrm{~h}$ before it was served at about $8.00 \mathrm{pm}$.

$S$ enteritidis PT4 was isolated from mixed samples of sea trout and stuffing. One of the remaining sea trout from the batch of three was obtained from the hostess's freezer. No salmonellae were isolated.

One egg from the same batch as used in the stuffing was available for examination but no salmonellae were isolated. These eggs were purchased at the same time as the trout and stored at room temperature. The flock which supplied the eggs was traced and $S$ enteritidis PT4 was isolated from batched viscera of 25 of 35 birds, from two cloacal swabs, from 55 birds, and from litter and dust from the henhouses. The flock was slaughtered under the Zoonoses Order, 1989.

\section{Discussion}

These three outbreaks show the difficulty of establishing the cause of food poisoning outbreaks, particularly where the infective agent is common and the implicated foodstuff not easily identifiable (such as a single brand of chocolate ${ }^{8}$ or salami ${ }^{9}$ ).
In outbreak 1 , cheesecake containing raw egg was the only food associated with symptoms. Other ingredients such as cream cheese and cream represent plausible but less likely sources of $S$ enteritidis PT4. The presence of two well $S$ enteritidis excretors who did not eat cheesecake may reflect either acquisition of lower numbers of organisms than required to cause illness, by consumption of other foods cross contaminated from the cheesecake, or, in one of the two, secondary spread from her three very ill flatmates. Outbreak 2 could be explained by cases eating either certain cold handled foods or egg containing foods. The tail of the epidemic curve (figure) suggests continuing cross contamination. Cold foods could have been contaminated by cross contamination from a batch of infected eggs or from poultry. The failure to detect $S$ enteritidis PT4, now very prevalent in chickens, does not, on its own, rule out poultry. Nevertheless it is improbable that contamination from poultry would selectively affect a whole range of foods containing eggs. Furthermore of eight types of sandwich only egg was significantly associated with illness. The most straightforward interpretation, therefore, of the data is that eggs were the original source and that cross contamination of other prepared foods subsequently occurred, as evidenced by the association of handled foods, including those not containing egg, with illness. In outbreak 3 stuffed sea trout was the only food associated with illness and $S$ enteritidis PT4 was isolated from it. Sea trout is not a recognised source of $S$ enteritidis PT4 and it was not isolated from a trout purchased from the same fishmonger's stall at the same time and stored in the same deep freeze but which was not stuffed. The stuffing was bound with egg and $S$ enteritidis was isolated from the laying flock.

These outbreaks are the latter three of seven consecutive egg associated $S$ enteritidis PT4 community outbreaks in Wales. ${ }^{10}$ Is it justifiable to claim that eggs were the cause? Certainly in the first two outbreaks kitchen inspection and/or food preparation histories suggested other vehicles of infection. In the first outbreak food handling practices led the initial investigation to conclude that turkey vol-aux-vents were the vehicle of infection. In the second outbreak the practice of thawing frozen chickens under running water suggested that splashing of sandwiches and other food might be the cause of the outbreak.

Reflecting Koch's postulates ${ }^{11}$ there is a public perception that a sample from the suspected meal containing the organism ${ }^{12}$ is required for proof that it is the source of infection. Only outbreak 3 would fulfil this criterion and even then the determined sceptic might claim that with such a common organism this merely constituted a coincidence and that sea trout was equally likely to be the source. Epidemiological studies, by contrast, demonstrate associations which invite an opinion or judgement about causality, not a claim of proof. ${ }^{13}$ Nevertheless, such opinion or judgement may not be dispassionate. As Gordis notes, ${ }^{14}$ "because epidemiologic findings have major political, economic and social implications, the discipline is itself strongly affected by prevailing attitudes and by the major issues that are of current concern to society". 
Breslow and Day ${ }^{15}$ and Schlesselman ${ }^{13}$ advance similar sets of seven criteria for assessing whether an association is likely to be causal. Do our data show, applying these seven criteria, that eggs are likely to be the cause of the outbreaks described?

(1) "Strength of association" 13 15 - In outbreaks 1 and 3 no-one who did not eat the egg containing foodstuff implicated epidemiologically became ill, and the relative risk therefore was technically infinite. In outbreak 2 the case-control study yielded an odds ratio for having eaten egg containing food of 5.0 for all cases and 8.0 for the subset of early cases. Cole writes ${ }^{16}$ : "Relative risks of less than 2.0 may readily reflect some unperceived bias or confounding factor, those over 5.0 are unlikely to do so". By this criterion egg containing foods were the cause of the early cases.

(2) "Specificity of risk"- "The specificity of risk to disease subgroups ... can be persuasive evidence of causality". ${ }^{15}$ The three outbreaks in which we have implicated eggs were all of $S$ enteritidis PT4, the species and phage type most usually associated with egg borne disease in the United Kingdom. ${ }^{17}$

This might also be viewed as (3) "considerations external to the study"15 supporting the conclusion that eggs caused the outbreaks. Schlesselmen includes "biological plausibility" in a similar broad category to this which he calls "collateral evidence". ${ }^{13}$ An egg borne infection with $S$ enteritidis PT4 is biologically plausible, particularly as transovarian infection of laying hens has been reported. ${ }^{18}$

In outbreak 2 the higher odds ratio for illness in early cases who ate egg containing foods is an example of (4) "specificity of risk to exposure subcategories". Early cases are more likely to have acquired their infection from the putative common source (eggs) rather than, say, by secondary transmission from other cases. Equally this could be viewed as evidence of (5) the "temporal relation of risk to exposure".

The data from the three outbreaks taken together are consistent. There is (6) a "lack of alternative explanations", despite careful investigation of all reasonable possibilities. In the first two outbreaks the epidemiological studies contradicted the initial bias of the investigators. Indeed, of the seven criteria for causality only (7), referred to as "dose response" by Breslow and Day and "biological gradient" by Schlesselman, is not fulfilled. Data to judge this were not available.

"Epidemiological standards for the practice of the newly re-established discipline in public health medicine-communicable disease control
- must be developed so that attributed causes of outbreaks are not left to be a 'matter of opinion"" ${ }^{19}$ In this article we have provided evidence implicating eggs in three consecutive outbreaks to fulfil six out of seven widely accepted criteria for establishing causation. If it is sensible to suggest that "we can measure distance from an absolute called proof" 20 and if proving the cause of food poisoning outbreaks is possible at all, then the cumulative evidence from these three outbreaks is well on the way to proof that eggs were a necessary, if not always of themselves a sufficient, cause.

We wish to acknowledge the help of Dr M P E Jenkins, Medical Officer for Environmental Health, Cardiff City Council, Dr A K Spence, Medical Officer for Environmental Health, Brecknock Borough Council, and the Division of Enteric Pathogens, PHLS, Central Public Health Laboratory, who typed the Salmonellae.

1 Anon. Anything to eat. Lancet 1989; i: $416-8$.

2 Grist NR. Foodborne infections and intoxications. $B M \mathcal{F}$ 1990; 300: 827-8.

3 Committee on the microbiological safety of food. The microbiological safety of food, part 1. London: HMSO, 1990. 4 Acheson D. The microbiological contamination of food. Health Trends 1988; 20: 6-9.

5 Sharp JCM. Salmonellosis and eggs. BMf 1988; 297: 1557-8.

6 Warden J. Richmond report on food safety. BMF 1990; 300: 491.

7 Coleman TJ, Salmon RL, Willis FJA, Allsup TN, Ritchie WN. Egg-stuffed sea trout and salmonellas. Communicable Disease Report 1989, 20th October (89/42).

8 Gill ON, Sockett PN, Bartlett CLR, et al. Outbreak of Salmonella napoli infection caused by imported chocolate bars. Lancet 1983; i: 574-7.

9 Cowden JM, O'Mahony M, Bartlett CLR, et al. A national outbreak of Salmonella typhimurium DT124 caused by contaminated salami sticks. Epidemiol Infect 1989; 103: 219-25. 10 Coyle EF, Palmer SR, Ribeiro CD, et al. Salmonella eggs. Lancet 1988; ii: 1295-7.

11 Thomas CGA Medical microbiology. 6th ed. London: Bailliere Tindall, 1986.

12 House of Commons Agriculture Committee. Salmonella in eggs. First report. Vol II (Minutes of Evidence and eggs. First report. Vol II (Minutes
Appendices). London: HMSO, 1989.

13 Schlesselman JJ. Case-control studies. New York: Oxford University Press, 1982.

14 Gordis $L$. Challenges to epidemiology in the next decade. Am $\mathcal{F}$ Epidemiol 1988; 128: 1-9.

15 Breslow NE, Day NE. Statistical methods in cancer research. Vol 1. The analysis of case-control studies. Lyon: International Agency for Research on Cancer, 1980.

16 Cole P. Introduction. In: Breslow NE, Day NE. Statistical methods in cancer research. Vol 1. The analysis of case control studies. Lyon: International Agency for Research on studies. Lyon:

17 Cowden JM, Lynch D, Joseph CA, et al. Case-control study of infections with Salmonella enteritidis phage type 4 in England. BMF 1989; 299: 771-3.

18 Humphrey TJ, Baskerville A, Moore S, Rowe B, Hopper S. Salmonella enteritidis phage type 4 from the contents of intact eggs: a study involving naturally infected hens. Epidemiol Infect 1989; 103: 415-23.

19 Palmer SR. Epidemiology in search of infectious diseases: methods in outbreak investigation. $\mathcal{F}$ Epidemiol Community Health 1989; 43: 311-4.

20 Marmot MG. Epidemiology and the art of the soluble. Lancet 1986; i: 897-900. 